\title{
Obestatin inhibits vasopressin secretion: evidence for a physiological action in the control of fluid homeostasis
}

\author{
Willis K Samson, Gina L C Yosten, Jaw-Kang Chang ${ }^{1}$, Alastair V Ferguson ${ }^{2}$ and Meghan M White \\ Department of Pharmacological and Physiological Science, Saint Louis University, 1402 South Grand Boulevard, St Louis, Missouri 63104, USA \\ ${ }^{1}$ Phoenix Pharmaceuticals Inc., 330 Beach Road, Burlingame, California 94010, USA \\ ${ }^{2}$ Department of Physiology, Queen's University, Botterell Hall, Kingston K7L 3N6, Canada \\ (Correspondence should be addressed to W K Samson; Email: samsonwk@slu.edu)
}

\begin{abstract}
Obestatin, a product of post-translational processing of the ghrelin prohormone, has been reported to act in the brain to inhibit thirst. We extended our initial studies on water drinking by examining the effects of obestatin on hypovolemia-induced water and saline drinking and vasopressin release in male rats. Intracerebroventricular administration of obestatin significantly inhibited water, but not saline $(0 \cdot 3 \mathrm{M} \mathrm{NaCl})$ drinking in response to a hypovolemic challenge. Obestatin also inhibited, in a dose-related fashion, dehydration-induced vasopressin secretion without affecting plasma oxytocin levels. Vasopressin release induced by central angiotensin II administration was
\end{abstract}

attenuated significantly by prior administration of obestatin. Finally, central administration of an antiserum specific to obestatin resulted in an exaggerated basal vasopressin release and an increased vasopressin response to overnight water deprivation. Antiserum treatment also resulted in significantly increased ad libitum water drinking and drinking in response to dehydration. We conclude that this product of post-translational processing of the ghrelin prohormone may be an important contributor to the physiologic regulation of fluid and electrolyte homeostasis.

Journal of Endocrinology (2008) 196, 559-564

\section{Introduction}

We have previously reported that obestatin, a 23 amino acid peptide derived from the same prohormone as ghrelin (Zhang et al. 2005), when injected into the lateral cerebroventricle inhibits water drinking in response to dehydration and angiotensin II administration (Samson et al. 2007). This antidipsogenic effect has been confirmed by Hsueh et al. (Zhang et al. 2007). While a number of studies have reported obestatin to inhibit food intake (Zhang et al. 2005, Bresciani et al. 2006, Sibilia et al. 2006, Green et al. 2007, Zizzari et al. 2007), other groups have not been able to reproduce such observations (Seoane et al. 2006, Chartrel et al. 2007, Nogueiras et al. 2007). In our hands the ability of obestatin to inhibit food intake appeared secondary to its action on water drinking (Samson et al. 2007). We also demonstrated direct neuronal actions of obestatin in subfornical organ (SFO), a potential site of action of peptides of both peripheral and central origin to inhibit not only water drinking, but also sodium appetite and vasopressin secretion. Here, we sought to determine if the antidipsogenic effect of obestatin could be extended to hypovolemia-induced thirst and salt appetite and if, in addition, the peptide could exert significant effects on vasopressin secretion. The physiological relevance of the pharmacological actions of obestatin was examined by passive immunoneutralization of endogenous obestatin.

\section{Materials and Methods}

\section{Animals}

All procedures have been approved by the animal care committee of Saint Louis University. Adult male rats (Sprague-Dawley, Harlan, Indianapolis, IN, USA) were maintained (12 h light:12 darkness cycle, lights-on $0600 \mathrm{~h}, 23-25{ }^{\circ} \mathrm{C}$ ) with ad libitum access to food and water, unless otherwise indicated. Under ketamine (Ketaset, Fort Dodge Animal Health, Fort Dodge, IA, USA)/xylazine (TranquiVed, Vedco Inc., St Joseph, MO, USA) anesthesia $(60 \mathrm{mg} / 8 \mathrm{mg}$ mixture $/ \mathrm{ml}, 0 \cdot 1 \mathrm{ml} / 100 \mathrm{~g}$ body weight, i.p. injection) rats were placed in a stereotaxic device and a 23 gauge, stainless steel cannula $(17 \mathrm{~mm})$ implanted into the right lateral cerebroventricle as described previously (Antunes-Rodrigues et al. 2004, Samson et al. 2007). Rats were allowed to recover to presurgery weights, minimally 5 days prior to experimentation. Placement and patency of the lateral ventricular cannula were verified (Samson et al. 2007) by the dipsogenic response to angiotensin II (50 pm A II).

Hypovolemia-induced thirst and salt appetite were examined with a two-bottle preference test (Blackburn et al. 1993). Rats were acclimated to two drinking bottles, one with tap water, the other with $0.3 \mathrm{M} \mathrm{NaCl}$, prior to experimentation. Animals were anesthetized by isoflurane gas inhalation $\left(3 \%\right.$ in $\mathrm{O}_{2}$ for induction, $2 \%$ in $\mathrm{O}_{2}$ for 
maintenance of anesthesia, IsoSol, Vedco, Inc.) and $5 \mathrm{ml}$ polyethylene glycol solution (PEG, Carbowax PEG 20 000; Fisher Scientific, Pittsburgh, PA, USA; of $15 \%$ weight/ volume in saline, $37^{\circ} \mathrm{C}$ ) injected subcutaneously. Animals were then denied access to food and water for $18 \mathrm{~h}$ to complete the hypovolemic challenge protocol (Blackburn et al. 1993). Ten minutes prior to returning the water and saline $(0 \cdot 3 \mathrm{M} \mathrm{NaCl})$ drinking bottles to the cages, either $2 \mu \mathrm{l}$ saline vehicle or vehicle containing $3.0 \mathrm{~nm}$ obestatin, a dose previously demonstrated by us to inhibit water consumption (Samson et al. 2007), was administered intracerebroventricularly. Cumulative intakes of water and saline were measured every $15 \mathrm{~min}$ for $1 \mathrm{~h}$ and every $30 \mathrm{~min}$ for the next $4 \mathrm{~h}$. Food was then returned to the cages and fluid intakes monitored once more at $24 \mathrm{~h}$. There were no significant differences in body weights between the rats administered obestatin or saline vehicle before or after the protocol was completed. Data were expressed in terms of $\mathrm{ml}$ water or saline consumed per $100 \mathrm{~g}$ body weight.

The effect of obestatin on physiologically driven vasopressin secretion was examined in rats deprived of water, but not food, for $18 \mathrm{~h}$ prior to experimentation. Animals were moved to a quiet room $2 \mathrm{~h}$ prior to injection of vehicle ( $2 \mu \mathrm{l}$, sterile $0.9 \%$ $\mathrm{NaCl}$, i.c.v.) or vehicle containing 1.0 or $3.0 \mathrm{~nm}$ obestatin (0900-1000 h). Rats were killed by decapitation 15 or $30 \mathrm{~min}$ later and trunk blood collected into heparinized tubes. Samples were maintained on ice and then centrifuged $\left(3000 \mathrm{~g}, 4^{\circ} \mathrm{C}\right.$, $30 \mathrm{~min}$ ) to allow collection of plasma for subsequent determination of vasopressin (AVP) and oxytocin (OT) levels by RIA (Samson 1985, Samson et al. 1985).

The effect of obestatin on pharmacologically driven vasopressin secretion was examined in ad libitum fed and watered rats (0900-1000 h). Water bottles were removed from the cages and animals administered $2 \mu \mathrm{l}$ saline vehicle (sterile $0.9 \% \mathrm{NaCl}$, i.c.v.) or vehicle containing 1.0 or 3. 0 nanomole obestatin, $10 \mathrm{~min}$ prior to the administration of A II (50 picomole in $2 \mu$ l, i.c.v., Qadri et al. 1993). Five minutes following A II injection, the rats were killed by decapitation and trunk blood collected as described above.

In a final series of experiments, the effects of central administration of anti-obestatin antiserum on vasopressin secretion and thirst were determined. The effect of antiobestatin treatment on basal vasopressin secretion was examined in ad libitum fed and watered rats. Two hours after being moved to a quiet room $(0900-1000 \mathrm{~h})$, the animals received an i.c.v. injection of $3 \mu \mathrm{l}$ normal rabbit serum (nonimmune serum, Sigma Chemical Co.) or $3 \mu \mathrm{l}$ anti-obestatin antiserum (H\&L purified, G-031-92, Phoenix Pharmaceuticals, Belmont, CA, USA). This antiserum is selective for obestatin and displays no cross-reactivity with ghrelin. Tissue staining for obestatin in the myenteric plexus is absent when this antiserum is preabsorbed with excess obestatin (Dunn et al. 2006). In addition, using this antiserum in western blot analysis of extracts of stomach and hypothalamus, a single band of immunoreactivity was detected that migrated similarly to synthetic obestatin (data not shown). Animals were left undisturbed with access to food and water for $1 \mathrm{~h}$, at which time they were killed by decapitation and trunk blood collected as described above.

The effect of anti-obestatin treatment on dehydrationinduced vasopressin secretion was examined in overnight water-restricted animals. Two hours after being moved to a quiet room, the animals received an i.c.v. injection of $3 \mu \mathrm{l}$ normal rabbit serum (NRS) or $3 \mu \mathrm{l}$ anti-obestatin antiserum as described above. Thirty minutes later, the rats were killed and trunk blood collected.

The effect of anti-obestatin administration on water and food intakes in ad libitum fed and watered animals was examined as described previously (Samson et al. 2007) with the exception that instead of i.c.v. administration of peptide, animals received cerebroventricular injections of $3 \mu \mathrm{l}$ normal rabbit serum or $3 \mu \mathrm{l}$ anti-obestatin antiserum, at the beginning of a 30-min interval of food and water restriction $(1530-1600 \mathrm{~h})$. Food and water were returned to the metabolic cages at $1600 \mathrm{~h}$ and intakes monitored at 30-min intervals until $2000 \mathrm{~h}$ and again at noon and $1600 \mathrm{~h}$ on the following day when the animals were weighed.

The effect of anti-obestatin administration on dehydrationinduced water drinking was examined in overnight waterrestricted (food present) animals. Two hours after being moved to a quiet room, the animals received an i.c.v. injection of $3 \mu \mathrm{l}$ normal rabbit serum or $3 \mu \mathrm{l}$ anti-obestatin antiserum as described above $(0900-1000 \mathrm{~h})$. Water bottles were returned to the cages $30 \mathrm{~min}$ later and intakes monitored for the following $5 \mathrm{~h}$ and again at $24 \mathrm{~h}$.

\section{Determination of plasma vasopressin and OT content}

AVP content in plasma was determined by RIA as described previously (Samson 1985) following extraction of $1.0 \mathrm{ml}$ plasma using C-18 chromatography. The lower limit of sensitivity of our AVP RIA (defined as $95 \% \mathrm{~B} / \mathrm{B}_{0}$ ) is $0.125 \mathrm{pg}$ per tube and the intra-assay variability determined in replicate serum pool samples was $<5 \%$. Since several assays were conducted during these experiments, we included samples from the same serum pool in each assay and the inter-assay coefficient of variability was $<6 \%$. Plasma OT levels were determined as described previously (Samson et al. 1985) following extraction using cold methanol $(0.3 \mathrm{ml}$ plasma/ $0.6 \mathrm{ml}$ methanol). The lower limit of detection of the OT RIA was $0.5 \mathrm{pg}$ per tube. The inter- and intra-assay coefficients of variability were $<8 \%$. Recoveries for both the AVP and OT extractions were consistently $>90 \%$. Values are reported as mean plasma hormone levels (pg/ml, \pm s.E.M).

\section{Statistical analysis}

Differences between groups or within groups across time were determined by ANOVA with Scheffe's multiple comparison testing. In experiments with only two experimental groups, the independent $t$-test was employed. An outcome with a probability of $<5 \%$ was considered significant. All data are presented as means and standard errors of the mean. 


\section{Results}

Central administration of $3.0 \mathrm{~nm}$ obestatin, a dose we have previously demonstrated to inhibit thirst (Samson et al. 2007), significantly reduced water, but not saline drinking, in response to PEG-induced hypovolemia (Fig. 1). The inhibition by obestatin attained significance after $2 \mathrm{~h}$ of drinking and remained significant for at least three more hours. There were no significant differences in water or saline intakes $24 \mathrm{~h}$ after the bottles were returned to the cages.

Anti-obestatin antiserum administration resulted in a significantly increased water drinking in ad libitum fed and watered rats (Fig. 2a). The effect was already apparent at the first $30 \mathrm{~min}$ of observation and remained significant $(P<0 \cdot 05)$ well into the lights-out period. Even at noon (antiserum-treated: $8 \cdot 1 \pm 1 \cdot 0$, NRS-treated: $6 \cdot 1 \pm 0 \cdot 9 \mathrm{ml} /$ $100 \mathrm{~g}$ body weight) and $1600 \mathrm{~h}$ (antiserum-treated: 10.0 \pm $1 \cdot 2$, NRS-treated: $8 \cdot 0 \pm 1 \cdot 0$ ) the following day, the animals in the antiserum treatment group continued to display increased, cumulative water intakes; however, these elevations did not attain statistical significance. Similarly, water intakes over the next 24-h interval did not differ significantly between groups (data not shown). While food intakes were elevated in antiserum-treated animals when compared with controls (Fig. 2b), these differences failed to reach a statistical significance at any time point. Body weights (data not shown) did not differ significantly between groups on the day prior to i.c.v. injections, or for the subsequent 3 days.

Antiserum administration significantly increased cumulative water drinking in overnight water-restricted rats (Fig. 3). The effect attained significance only at $4(P<0 \cdot 5)$ and $5(P<0 \cdot 01) \mathrm{h}$ following water bottle return; however, it remained statistically significant $24 \mathrm{~h}$ later $(P<0 \cdot 001)$. Again, body weights did not differ between treatment groups.

Plasma AVP levels were significantly elevated following overnight water restriction (see Fig. 4a, dehydrated controls versus Fig. 5, normally hydrated controls). Obestatin administration i.c.v. significantly lowered the plasma AVP

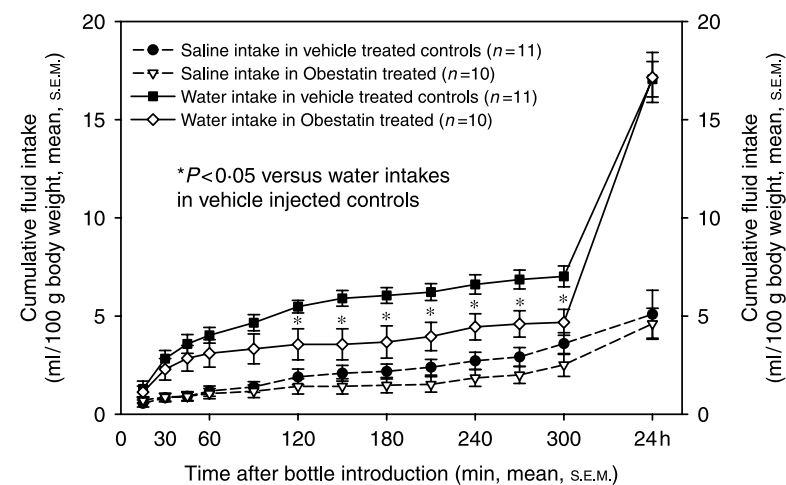

Figure 1 Intracerebroventricular administration of $3 \cdot 0 \mathrm{~nm}$ obestatin significantly inhibits water drinking, but not saline drinking, in male rats following polyethylene glycol-induced hypovolemia. ${ }^{*} P<0 \cdot 05$ versus water intake in vehicle-treated controls.
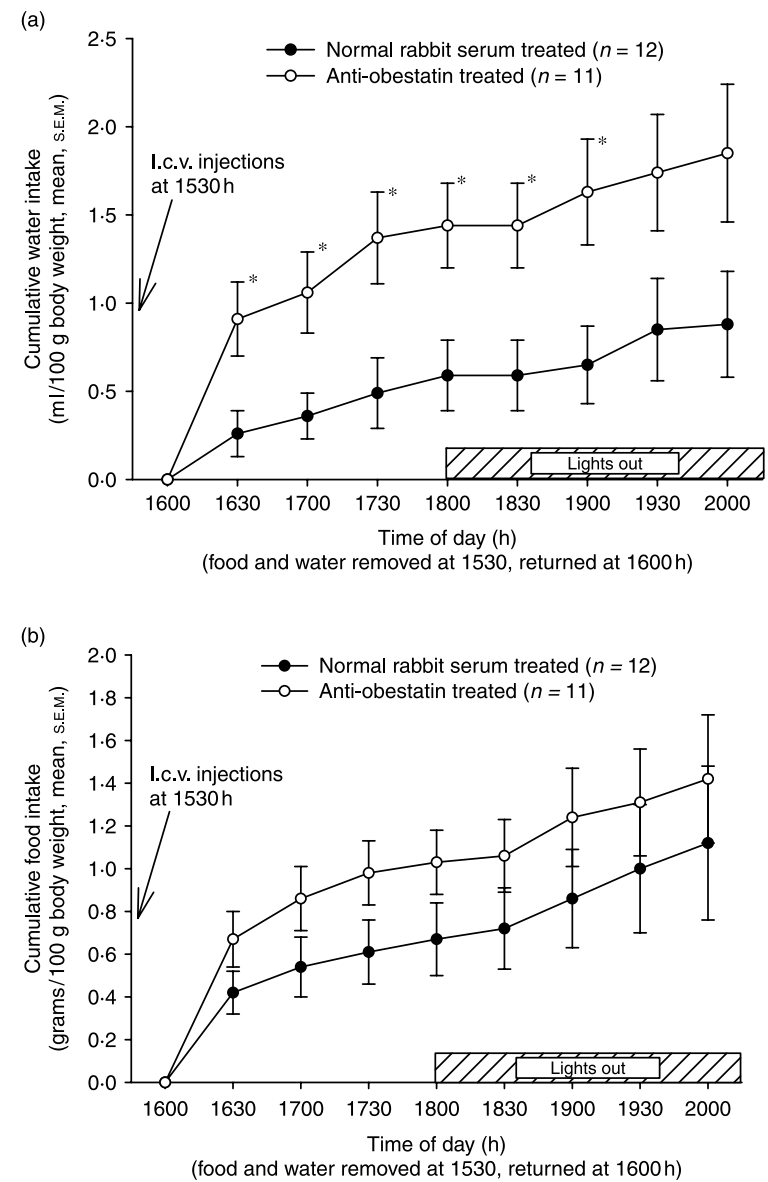

Figure 2 Effect of passive immunoneutralization of endogenous obestatin on (a) ad libitum water drinking and (b) food intake in male rats. ${ }^{*} P<0 \cdot 05$ versus intakes in NRS-treated controls.

levels in water-restricted animals without significantly altering plasma OT levels (Fig. 4b). The inhibitory action of obestatin on AVP secretion at $15 \mathrm{~min}$ was dose-related $(1 \cdot 0 \mathrm{~nm}$ obestatin, $P<0 \cdot 05 ; 3 \cdot 0 \mathrm{~nm}$ obestatin, $P<0 \cdot 001$;

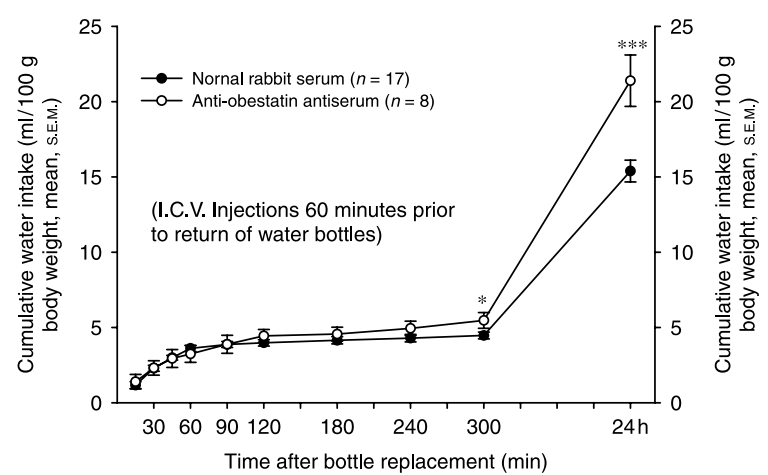

Figure 3 Effect of passive immunoneutralization of endogenous obestatin on water drinking in overnight water-restricted male rats. $* P<0 \cdot 05, * * * P<0.001$ versus intakes in NRS-treated controls. 

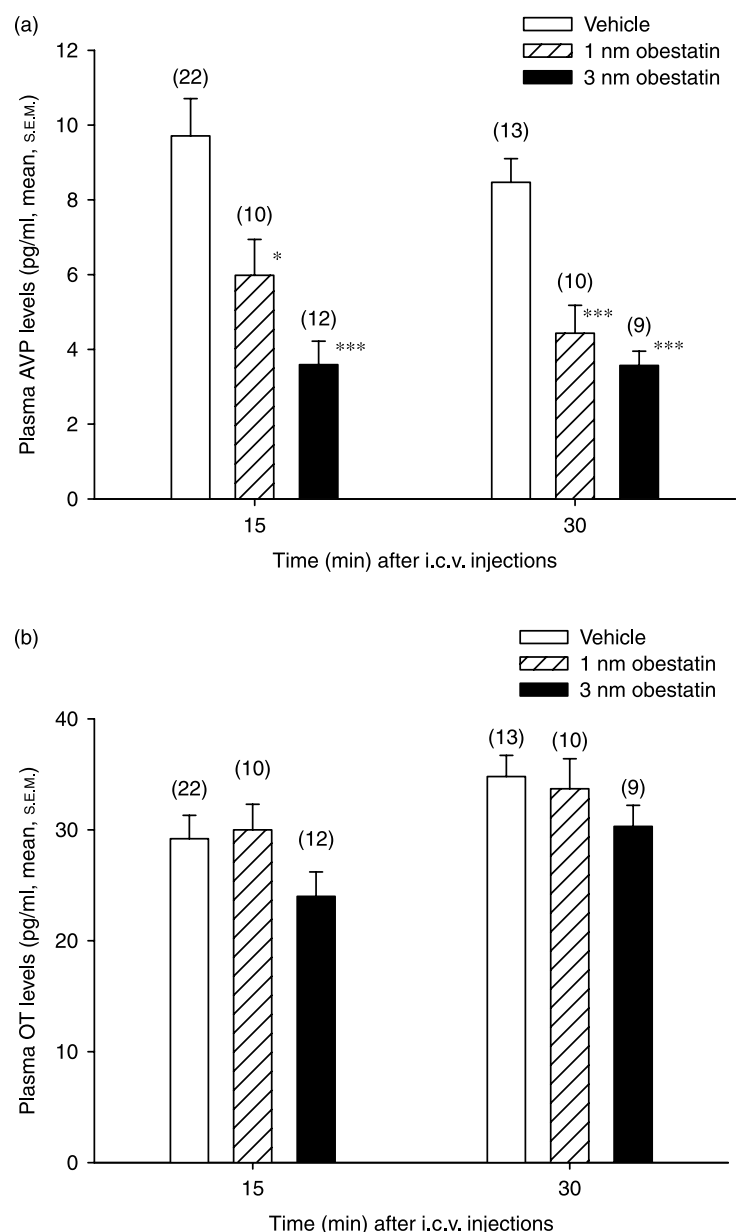

Figure 4 Intracerebroventricular administration of obestatin significantly reduces overnight dehydration-induced vasopressin (a) but not oxytocin (b) levels in male rats. ${ }^{*} P<0 \cdot 05,{ }^{* * *} P<0 \cdot 001$ versus levels present in vehicle-treated controls.

obestatin versus vehicle) and was still evident $30 \mathrm{~min}$ after peptide administration $(P<0 \cdot 001$, both the doses $)$.

Central administration of $50 \mathrm{pm}$ angiotensin II resulted in a significant elevation of plasma AVP levels $(P<0 \cdot 001)$, without any significant effect on plasma levels of OT (Fig. 5). Pretreatment with 1.0 or $3.0 \mathrm{~nm}$ obestatin $10 \mathrm{~min}$ prior to the angiotensin II administration resulted in a significant reversal of the stimulatory actions of angiotensin II. The AVP levels in angiotensin II-administered animals pretreated with $1.0 \mathrm{~nm}$ obestatin were significantly lower than those in saline-pretreated rats $(P<0 \cdot 05)$, but still significantly greater than levels in control animals (salinepretreated, saline-administered instead of angiotensin II, $P<0 \cdot 05)$. On the other hand, plasma AVP levels in rats pretreated with $3.0 \mathrm{~nm}$ obestatin and then administered angiotensin II did not differ significantly from those present in saline-pretreated and saline-administered controls. OT levels were not affected by obestatin administration.

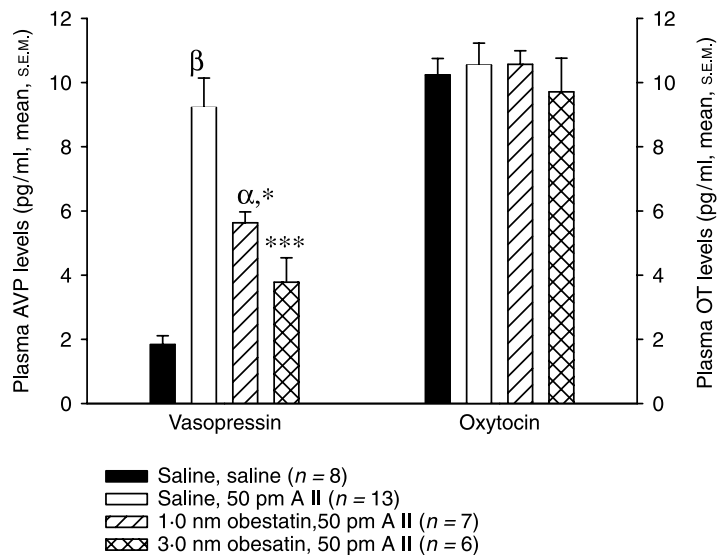

Figure 5 Intracerebroventricular administration of angiotensin II significantly elevates plasma vasopressin, but not oxytocin, levels in normally hydrated rats and this effect is significantly reduced by pretreatment with obestatin. ${ }^{*} P<0 \cdot 05,{ }^{* * *} P<0 \cdot 001$ versus salinepretreated, A II-injected rats. ${ }^{\alpha} P<0.05$ versus saline-pretreated, saline-injected controls. ${ }^{\beta} P<0 \cdot 001$ versus saline-pretreated, salineinjected controls.

Basal AVP levels in ad libitum fed and watered animals were significantly elevated following i.c.v. administration of antiobestatin antiserum $(4 \cdot 2 \pm 0 \cdot 5 \mathrm{pg} \mathrm{AVP} / \mathrm{ml}$ plasma, $n=15)$ compared with levels present in NRS-treated controls $(1 \cdot 4 \pm$ $0 \cdot 2, n=8)$. Plasma AVP levels present in NRS-treated controls did not differ significantly from untreated or salineinjected controls.

The elevated plasma AVP levels observed in water-restricted animals administered normal rabbit serum i.c.v. were not significantly different than those observed in water-restricted control animals (Fig. 6). However, plasma AVP levels were significantly elevated above control in water-restricted animals administered anti-obestatin antibodies $30 \mathrm{~min}$ before killing. Plasma OT levels were not significantly altered by non-immune serum or anti-obestatin administration.

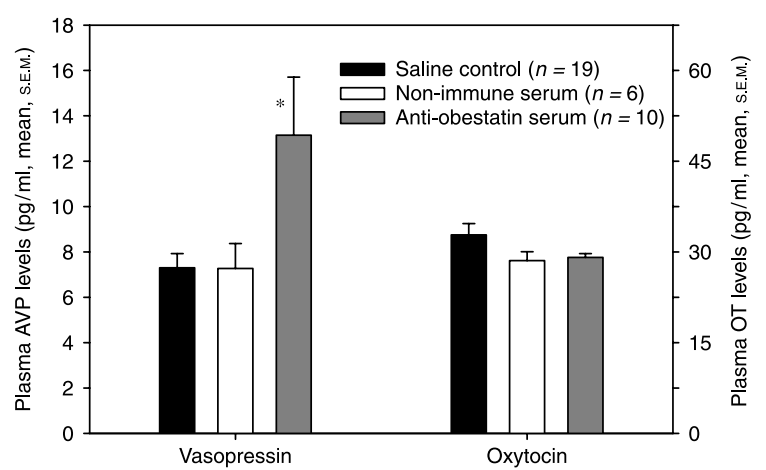

Figure 6 Intracerebroventricular administration of anti-obestatin antibodies significantly elevates dehydration-induced vasopressin, but not oxytocin, secretion in male rats. ${ }^{*} P<0 \cdot 05$ versus vehicle- or normal rabbit serum (non-immune serum)-injected controls.

www.endocrinology-journals.org 


\section{Discussion}

We have extended our earlier studies on the central actions of obestatin on water drinking behavior (Samson et al. 2007) by demonstrating that in response to hypovolemia, obestatin selectively inhibits water, but not $0.3 \mathrm{M} \mathrm{NaCl}$ drinking. More importantly, both physiologically and pharmacologically driven AVP secretion is inhibited by similar doses of obestatin. The effect appeared to be selective for AVP, as plasma levels of OT remained unaffected. Thus, it is not surprising that in the two-bottle preference test (PEGinduced hypovolemia) we observed no effect of obestatin on saline drinking, a behavior influenced by OT release (Blackburn et al. 1993). The pharmacologic action of obestatin to inhibit AVP secretion may have physiologic relevance since passive immunoneutralization of endogenous obestatin resulted in exaggerated AVP levels under basal conditions and in response to water deprivation. Furthermore, the antidipsogenic effects of synthetic obestatin appear to reflect a potentially important action of the endogenous peptide to restrain water drinking since both ad libitum and dehydration-induced water intakes were significantly elevated in anti-obestatin treated animals. As in our previous publication (Samson et al. 2007), we conclude that any effects of obestatin of exogenous or endogenous origin on feeding are likely to be secondary to its antidipsogenic action since cumulative food intakes did not differ significantly between antiserum and NRS-treated animals.

These studies do not identify the specific site of action of obestatin to inhibit thirst or vasopressin secretion; however, we have previously reported that obestatin exerts direct membrane effects on dissociated SFO neurons (Samson et al. 2007). Thus, it is possible that in these studies obestatin exerted its antidipsogenic and AVP inhibiting effects within the SFO. Although controversy exists (Lauwers et al. 2006, Moechars et al. 2006, Holst et al. 2007, Tremblay et al. 2007), to date the only identified receptor that may bind obestatin in vivo is $\mathrm{G}$ protein-coupled receptor 39 (GPR39). In one study (Jackson et al. 2006), GPR 39 mRNA was not observed in the hypothalamic sites; however, in the original description of obestatin, Zhang et al. 2005 were able to demonstrate the presence of the message in mouse hypothalamus by reverse transcriptase-PCR methodologies. It is not clear whether or not the SFO was included in the tissues examined by either group. While the original identification of GPR39 as a possible receptor for obestatin remains to be verified, it is possible that another, yet to be identified receptor mediates the actions of the peptide. Alternatively, additional splice variants of the GPR 39 gene product (Egerod et al. 2007) may exist in the hypothalamus, which were not detected in the initial studies (Jackson et al. 2006). The SFO and perhaps more directly the paraventricular or supraoptic nuclei remain attractive potential sites for the effects of the peptide described here, since we administered obestatin in our animals behind the blood-brain barrier. At least three other groups have reported the cellular effects of obestatin behind the bloodbrain barrier (Dunn et al. 2006, Szentirmai \& Krueger 2006, Carlini et al. 2007) and, because it has been reported that peripherally administered obestatin is cleared from the circulation very quickly and not likely to cross the barrier (Pan et al. 2006), we hypothesize that our passive immunoneutralization results reflect the sequestration of brain-derived obestatin, released from populations of preproghrelin expressing neurons previously reported in multiple CNS sites (Koijima \& Kangawa 2005). Indeed, the antiserum we employed in that study has been demonstrated to be specific for obestatin as preabsorption with synthetic obestatin eliminated the immunohistochemical identification of obestatin-positive cells in myenteric plexus, cells that also stain positively for preproghrelin (Dunn et al. 2006), and immunoreactive obestatin extracted from stomach and hypothalamus is visualized as a single band with appropriate mobility in western blot analysis.

In summary, we have demonstrated that in addition to a pharmacologic action to inhibit water drinking, obestatin acts in the brain to reduce the secretion of AVP in response to both pharmacologic and physiologic stimuli. We hypothesize that the complementary actions of obestatin to inhibit thirst and AVP secretion reflect a physiologically relevant action of the endogenous peptide to buffer total body fluid content. Certainly, our demonstration that the central administration of anti-obestatin antibodies results in an exaggerated AVP secretion under basal conditions, and in response to water deprivation, suggests that these pharmacologic effects of the peptide may have a physiologic relevance. Indeed, the ability of the passive immunoneutralization of endogenous obestatin to elevate basal AVP levels in ad libitum fed and watered rats suggests that brain-derived peptide may function to protect the animal against inappropriate secretion of that hormone. Much remains to be learned about the regulation of obestatin production and release, its sites of action, and its full biologic activity; however, our findings described here and previously (Samson et al. 2007) do draw attention to both behavioral and endocrine actions of the peptide that may provide further insight into the physiology of fluid homeostasis.

\section{Acknowledgements}

This work was supported by NIH Grant HL66023 to W K S and A V F. The authors have no conflict of interest to disclose.

\section{References}

Antunes-Rodrigues J, de Castro M, Elias LL, Valencia MM \& McCann SM 2004 Neuroendocrine control of body fluid metabolism. Physiological Reviews 84 169-208.

Blackburn RE, Samson WK, Fulton RJ, Stricker EM \& Verbalis JG 1993 Central oxytocin inhibition of salt appetite in rats: evidence for differential sensing of plasma sodium and osmolality. PNAS 90 10380-10384. 
Bresciani E, Rapetti D, Dona F, Bulgarelli I, Tamiazzo L, Locatelli V \& Torsello A 2006 Obestatin inhibits feeding but does not modulate GH and corticosterone secretion in the rat. Journal of Endocrinological Investigation 29 RC16-RC18.

Carlini VP, Schioth HB \& Debarioglio SR 2007 Obestatin improves memory performance and causes anxiolytic effects in rats. Biochemical and Biophysical Research Communications 352 907-912.

Chartrel N, Alvear-Perez R, Leprince J, Iturrioz X, Reaux-Le Goazigo A, Audinot V, Chomarat P, Coge F, Nosjean O, Rodriguez M et al. 2007 Comment on 'Obestatin, a peptide encoded by the ghrelin gene, opposes ghrelin's effects on food intake'. Science 315 766-767.

Dunn SL, Brailoiu GC, Brailou E, Yang J, Chang JK \& Dun NJ 2006 Distribution and biological activity of obestatin in the rat. Journal of Endocrinology 191 481-489.

Egerod KL, Holst B, Petersen PS, Hansen JB, Mulder J, Hoekfelt T \& Schwartz TW 2007 GPR39 splice variants versus antisense gene LYPD1expression and regulation in gastrointestinal tract, endocrine pancreas, liver and white adipose tissue. Molecular Endocrinology 21 1685-1698.

Green BD, Irwin N \& Flatt PR 2007 Direct and indirect effects of obestatin peptides on food intake and the regulation of glucose homeostasis and insulin secretion in mice. Peptides 28 981-987.

Holst B, Egerod KL, Schild E, Vickers SP, Cheetham S, Gerlach LO, Storjohann L, Stidsen CE, Jones R, Beck-Sickinger AG et al. 2007 GPR 39 signaling is stimulated by zinc ions but not by obestatin. Endocrinology 148 13-20.

Jackson VR, Nothacker HP \& Civelli O 2006 GPR39 receptor expression in the mouse brain. Neuroreport 17 813-816.

Koijima M \& Kangawa K 2005 Ghrelin: structure and function. Physiological Reviews 85 495-522.

Lauwers E, Landuyt B, Arckens L, Schoofs L \& Luyten W 2006 Obestatin does not activate orphan $\mathrm{G}$ protein-coupled receptor GPR39. Biochemical and Biophysical Research Communications 351 21-25.

Moechars D, Depoortere I, Moreaux B, DeSmet B, Goris I, Hoskins L, Daneels G, Kass S, VerDonck L, Peeters Tet al. 2006 Altered gastrointestinal and metabolic function in the GPR39-obestatin receptor-knockout mouse. Gastroenterology 131 1131-1141.

Nogueiras R, Pfluger R, Tovar S, Arnold M, Mitchell S, Morris A, Perex-Tilve D, Vazquez MJ, Wiedmer P, Castaneda TR et al. 2007 Effects of obestatin on energy balance and growth hormone secretion in rodents. Endocrinology 148 21-26.

Pan W, Tu H \& Kastin AJ 2006 Differential BBB, interactions of three ingestive peptides: obestatin, ghrelin, and adiponectin. Peptides 27 911-916.
Qadri F, Culman J, Veltmar A, Maas K, Rascher W \& Unger T 1993 Angiotensin II-induced vasopressin release is mediated through alpha-1 adrenoceptors and angiotensin II, AT1 receptors in supraoptic nucleus. Journal of Pharmacology and Experimental Therapeutics 267 567-574.

Samson WK 1985 Atrial natriuretic factor inhibits dehydration and hemorrhage-induced vasopressin release. Neuroendocrinology 40 277-279.

Samson WK, McDonald JK \& Lumpkin MD 1985 Naloxone dissociates stress-induced oxytocin and prolactin releases. Neuroendocrinology $\mathbf{4 0}$ $68-70$

Samson WK, White MM, Price CP \& Ferguson AV 2007 Obestatin acts in brain to inhibit thirst. American Journal of Physiology 292 R637-R643.

Seoane LM, Al-Massadi O, Pazoz Y, Pagotto U \& Casaneuva FF 2006 Central obestatin administration does not modify either spontaneous or ghrelin-induced food intake in rats. Journal of Endocrinological Investigation 29 RC13-RC15.

Sibilia V, Brescani E, Lattuada N, Paetti D, Locatelli V, DeLuca V, Dona F, Netti C, Torsello A \& Guidobono F 2006 Intracerebroventricular acute and chronic administration of obestatin minimally affect food intake but not weight gain in the rat. Journal of Endocrinological Investigation 29 RC31-RC34.

Szentirmai E \& Krueger JM 2006 Obestatin alters sleep in rats. Neuroscience Letters 404 222-226.

Tremblay F, Perrault M, Klaman LD, Tobin JF, Smith E \& Gimeno RE 2007 Normal food intake and body weight in mice lacking the $\mathrm{G}$ proteincoupled receptor GPR39. Endocrinology 148 501-506.

Zhang JV, Ren JG, Avsia-Kretchmer O, Luo CW, Rauch R, Klein C \& Hsueh AJW 2005 Obestatin, a peptide encoded by the ghrelin gene, opposes ghrelin's effect on food intake. Science 310 996-999.

Zhang JV, Klein C, Ren PG, Kass S, VerDonk L, Moechars D \& Hsueh AJW 2007 Response to comment on 'Obestatin, a peptide encoded by the Ghrelin gene, opposes effects on food intake'. Science 315766.

Zizzari P, Longchamps R, Epelbaum J \& Bluet-Pajot MT 2007 Obestatin partially affects ghrelin stimulation of food intake and growth hormone secretion in rodents. Endocrinology 148 1648-1653.

Received in final form 26 October 2007

Accepted 27 November 2007

Made available online as an Accepted Preprint

27 November 2007 